\title{
Welfare conditionality, sanctions and homelessness: meanings made by homeless support workers
}

Meanings made by homeless support workers

\author{
Kelly Veasey
}

Department of Social Sceinces and Social Work, Bournemouth University, Poole, UK and School of Social Policy, Sociology and Social Research (SSPSSR), University of Kent, Canterbury, UK, and

Jonathan Parker

Department of Social Sceinces and Social Work, Bournemouth University, Poole, UK

\begin{abstract}
Purpose - This study aims to explore homeless-support workers' perceptions of homeless welfare recipients and their experiences of navigating new conditions placed upon them by UK welfare reform. It examines support workers' views of the most punitive feature of the welfare system, sanctions, on those recipients.

In 2012, the Conservative and Liberal Democrat Coalition Government introduced the largest and most radical overhaul of the UK benefit system, significantly increasing the level of conditionality and sanctions for noncompliance, part of a shift in welfare, suggesting that rights must be balanced by responsibility and the "culture of worklessness" and "benefit dependency" should be addressed.

Design/methodology/approach - Welfare reforms in the UK and the increased use of sanctions as part of welfare conditionality are reviewed. Data are collected from eight semi-structured interviews taking place in five housing support groups in the South East and South West of England in 2019-2020. The interviews followed an approach from interpretive phenomenological analysis.

Findings - Findings from this study indicate that the government's reforms serve as a disciplinary measure for the poor, reinforcing inequality and social marginalization. To mitigate the effects would require a comprehensive review of universal credit prior to its full rollout to claimants. Data are analyzed thematically.

Originality/value - Welfare conditionality and welfare reform is well-researched in the UK. There is also a significant volume of research concerning homelessness. This paper, however, fills a gap in research concerning the experiences of those working in housing support agencies working with homeless people in the UK.
\end{abstract}

Keywords Homelessness, Universal Credit, Welfare conditionality

Paper type Research paper

\section{Introduction}

In 2012, the Conservative and Liberal Democrat Coalition Government enacted the toughest regime of welfare sanctions and conditionality in the history of the UK benefit system,

(C) Kelly Veasey and Jonathan Parker. Published in Journal of Humanities and Applied Social Sciences. Published by Emerald Publishing Limited. This article is published under the Creative Commons Attribution (CC BY 4.0) licence. Anyone may reproduce, distribute, translate and create derivative works of this article (for both commercial and non-commercial purposes), subject to full attribution to the original publication and authors. The full terms of this licence maybe seen at http://creativecommons.org/licences/by/4.0/legalcode

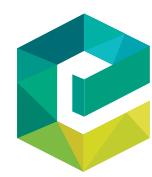

Received 10 December 2020 Revised 19 January 2021 
$\underset{4,4}{\text { JHASS }}$

276

drastically expanding the scale of conditions imposed upon welfare recipients and severity of sanctioning for non-compliance (Edmiston, 2017; Fletcher and Wright, 2018; Reeve, 2017).

Central to these reforms is universal credit (UC), which was implemented against the backdrop of ongoing austerity and marked by "savage" cuts to public expenditure, disproportionately impacting post-industrial areas with greater rates of welfare receipt, unemployment and poverty (Cheetham et al., 2019).

Since its inception, UC has attracted widespread critical attention concerning the ways in which particular design issues risk increasing rent arrears, evictions and homelessness. There is a long waiting period between the initial claim and obtaining the first payment during which the claimant is often left without the financial means for rent (Kleynhans and Weekes, 2019). This has been enhanced by the switch to direct monthly payments, from the previous fortnightly payments of benefits with the housing element paid directly to the claimant's landlord. This new concept has been criticized for the repercussions it has for the housing safety net.

The toughened use of conditionality and sanctions have been extended to those in paid employment whose hours fall under the conditionality threshold (Dwyer and Wright, 2014). This, as Beatty and Fothergill (2018) explain, often puts claimants under pressure to pay their rent while sanctions are reducing their income. Subsequently, those lacking skills in budgeting, or "borrowing" from the housing element of UC to cover essential costs, will struggle to afford their rent (Homeless Link, 2018).

These design issues have led to a great deal of apprehension about the impact of the regime on homelessness and other vulnerable citizens, with widespread concerns of increased rent arrears and eviction, particularly for those with disabilities, physical and mental health problems and difficulties with online access, literacy and language (Cheetham et al., 2019; Reeve, 2017; Wright et al., 2016). These effects are likely to be felt in the third sector, with increased workload and financial pressures as more vulnerable claimants are in need of support to claim UC and manage the associated requirements (Geiger et al., 2018; Howarth et al., 2018). Barker (2018) found that claimants of UC were twice as likely to face eviction than those under the previous welfare system. This has led to the United Nations Rapporteur releasing a coruscating analysis of many of the features of UC and Department of Work and Pensions (Alston, 2018). There are substantial gaps in the literature investigating enhanced conditionality, sanctions and the potential relationship to homelessness in all its forms (Bramley and Fitzpatrick, 2018). In UK Legislation, a household is considered homeless if they have to seek assistance from local authorities because of the imminent loss or loss of accommodation (as set out in Part VII 175 of the Housing Act 1996, amended by the Homelessness Act 2002; Localism Act 2011 and the Homelessness Reduction Act 2017). This may exclude numerous groups of people, including rough sleepers. As a result, in this paper, we accept a broad definition of homelessness, recognizing it is complex and multi-faceted and relating to those who are roofless, living in inadequate or precarious housing (Olsen and Benjaminsen, 2019). In particular, we focus on those with whom housing support workers come into contact.

This article explores the subjective experiences of third-sector workers, namely, those working in areas of housing, voluntary and community sectors. This aims to illuminate the impact of UC's harsh conditionality and sanctioning measures on housing security, however, unintentional, for the most vulnerable and marginalized claimants as perceived by third-sector workers, people deemed to be homeless.

\section{Conditionality, sanctions and the punitive turn}

Despite fluctuations in welfare entitlement, the trajectory of welfare reform was characterized by a great amount of continuity between 1979 and 2010, that is the overriding 
intention "to get Britain working again" (Department for Work and Pensions, 2014). With citizenship increasingly predicated on the emergence of homo economicus, the status and praxis of welfare entitlement has slowly shifted to one of the "creeping conditionality" (Dwyer, 2004) and "instrumental behaviorism" (Fletcher and Wright, 2018), by which welfare reforms decreased the extent of unconditional entitlement and amplified the practice of conditionality (Wright, 2012).

During the 1980s, mass unemployment paired with cost-cutting pledges and ideological predictions led the Conservative Government (1979-1997) to commission a number of social security assessments and institute a "harsher welfare regime" (Dwyer and Wright, 2012; Reeve, 2017). Tougher eligibility criteria for unemployment benefits were instituted (Fletcher and Wright, 2018), including the Restart Programme in 1987, which meant benefits could be reduced or suspended if claimants failed to attend compulsory "restart" interviews as part of "genuine" attempts to find work. Reforms also led to a yearly devaluation of already insufficient benefit rates (Dean, 2004), representing the genesis of the ongoing shift from welfare as a right to the conditional obligations of workfare (Dean, 2010). However, it was the implementation of jobseeker's allowance (JSA) in 1996 that was a critical juncture (Fletcher and Wright, 2018).

Conditions attached to JSA strengthened behavioral conditionality (claimant expectation to comply with a specific set of behavioral patterns) with the launch of mandatory back-towork plans (jobseeker's agreement) and job-search diaries (Dwyer, 2016). These conditions increased surveillance and mandation practices, such as new jobseeker directives, which extended power to employability advisors who could require claimants to alter their personal conduct and/or appearance if they felt either hindered their chances to secure paid employment or risk benefit disqualification (Fletcher and Wright, 2018).

The punitive turn was firmly established by the time (New) Labor came into power in 1997 (Reeve, 2017). Their adoption of the conservative's JSA policy indicated a continuing consensus on coercive conditionality (Driver, 2009; Dwyer and Wright, 2014). The (New) Labor Government's approach to tackling social exclusion through homelessness emphasized providing "solutions" and support for claimants with multiple complex needs. Welfare conditionality, alongside greater investment in support services, assumed homeless claimants would comply with the measures pushing them into employment; seeing this as a more appealing alternative to "doing nothing" while "living on the street." This included the establishment of the Supporting People program to fund organizations providing housing and homelessness assistance, with organizations working on a "move-on" model, characterized by a defined timeframe and level of support for individuals to develop the skills to prepare them for independent living (Dobson and McNeill, 2011; Jones, 2019).

Means testing became a progressively important characteristic of working-age social security (Watts et al., 2014) and targeted those on low incomes or with long-term illnesses and/or disabilities (Edmiston, 2017; Dwyer, 2016; Reeve, 2017). Benefit uprating was subject to the target demographic and, over time, the value of working-age social security was decreasing (Pennycook and Whittaker, 2012).

At the 2010 general election, there was a common political consensus on the necessity to "revise" the welfare contract, increase individual responsibility and ensure that all those who are able to work are taking the necessary steps to do so or risk benefit sanctions (Lister and Bennett, 2010). The three main political parties contended to provide the "toughest" benefit reform (Edmiston, 2017).

The Conservative and Liberal Democrat Coalition Government (2010-2015) aimed to generate a policy and political mandate for welfare state fiscal consolidation and retrenchment strengthened by claims that the profligate welfare system was the cause of
Meanings made by homeless support workers 
JHASS 4,4

public sector debt and welfare dependency (Department for Work and Pensions, 2010a; Gibson, 2015). A variety of discursive approaches that sought to address "welfare dependency" and problematized "cultures of worklessness" were mobilized (Reeve, 2017). Such approaches are powerful at promoting an "anti-welfare common sense," even for those in receipt of low-income social security (Edmiston, 2017).

The government deployed terms such as "skiver" and "scrounger" to promote the reductive worldview of benefit claimants as only taking and never giving back to society; living in "entitled" contentedness and "undeserving" of state support or empathy (O'Hara, 2020). Subsequently, policy agendas of fiscal consolidation and welfare reform have become firmly interlocked, with each gaining its policy imperative and political legitimacy from the other (Lee, 2011).

The Coalition Government (2010-2015) continued the "work first" approach (Fletcher et al., 2016). However, in 2012, the government introduced an even tougher strategy that involved the growth and rapid intensification of benefit sanctions (Dwyer and Wright, 2012), with the underlying goal of making a total net saving of £2.5bn (Office for Budget Responsibility, 2019). The sanction regime operates alongside UC, the current main working-age benefit that replaced six existing social security benefits with a single meanstested payment and intending to meet the needs of those in a variety of work and non-work circumstances (Department for Work and Pensions, 2010a, 2010b; Dwyer and Wright, 2012). UC superseded Working Tax Credits for those in paid employment, introducing new expectations for part-time workers to seek out extra pay and hours for up to $35 \mathrm{~h}$ per week (Bennett, 2012). Part-time workers and those out of work (unless deemed medically unable) were required to search for work (including logging job searches and attending nonnegotiable workfare placements), or risk being sanctioned for non-compliance, escalating from 91 days for the first case, to 182 days for a second offence and 1,095 days in the third instance (Department for Work and Pensions, 2012; Pennycook and Whittaker, 2012). Conditionality and sanctions were used to coerce people into low-paid and precarious work (Standing, 2016). This promoted a concept of conditionality unlike anything previously seen in the British welfare system (Fletcher and Wright, 2018).

Because those facing homelessness and housing insecurity were more likely to be sanctioned, the government introduced the JSA Easements Amendment Regulations in 2014. This new legislation allowed jobcenter staff to offer conditionality "easements" in an attempt to support rough sleepers to find suitable and sustainable accommodation which, it was thought, would break down barriers to obtaining paid employment. However, these measures were discretionary on whether their rough sleeping constituted as a "domestic emergency" and depended upon the claimant taking "reasonable action" to secure accommodation (Anderson, 2014).

The impact of UC on housing security has been subject to widespread critical attention, specifically, the long wait between making the UC application and receiving initial payment. The delay period is intended to be five weeks but has proven to take longer in many instances (Kleynhans and Weekes, 2019). This appears particularly prevalent among vulnerable claimants who face longer delays between registration and declaration of their claims, often struggling to navigate the online system and not receiving the adequate support (Jeffrey, 2018). Cheetham et al. (2019) found that claimants are often left without the financial means to pay their rent, leading to mounting arrears and increasing the risk of eviction. In an attempt to reduce this, the Department for Work and Pensions (DWP) have provided housing benefit claimants a two-week extension during the changeover period; those requiring immediate financial assistance are provided with an advanced payment. 
DWP ministers have emphasized the success of these safeguards in reducing rent arrears (Department for Work and Pensions, 2017).

Yet, an advanced payment is effectively a loan that will need to be repaid via deductions on subsequent UC payments, which are unsuitable for low-income households (Crisis, 2018). This often leaves claimants struggling to uphold their tenancy, particularly as they are still adjusting to the new system (House of Commons Work and Pensions Committee, 2018). Additionally, Cheetham et al. (2019) found that the repayment system was inadequately explained and understood by claimants, impacting their family and social life and causing serious hardship. Claimants, where possible, had to borrow from family and friends and often had to go without food and utilities just to get by and avoid going into debt and rent arrears.

Also, prolonged and intensified conditionality implemented under UC has led to greater sanction rates than previous systems (Dwyer and Wright, 2014; Webster, 2019). Indeed, UC's enhanced conditionality regime and sanction rates have made it increasingly difficult for claimants to afford rent, reducing their housing security while increasing their vulnerabilities and distress (Beatty et al., 2015). As a result, prior to COVID-19, rent arrears have led to many claimants facing repossession action; with staff from local governments, health services and community support groups reporting added pressure as they have seen an increase in households seeking support from third-sector organizations (Cheetham et al., 2019). Although there are safeguards in place to protect individuals with complex needs, Patrick (2012) found that these were not always applied correctly, seeing individuals wrongly subject to conditionality and unfair benefit sanctioning.

Sanctions have led to an increase in hardship payment applications (House of Commons Work and Pensions Committee, 2018). However, the aggressive repayment system of up to $40 \%$, on subsequent UC payments, has accentuated claimants' budgeting difficulties. The House of Commons Work and Pensions Committee (HCWPC, 2018) indicate that third-sector organizations have reported that the majority of their clients with the repayment deductions struggled to keep up with household bills and cover essential expenditure, with some resorting to other forms of loans and credit, which leads to increasing debt and ultimately to housing insecurity (Keen, 2018).

The move to monthly payments is intended to simulate and prepare claimants to manage a working salary (Pennycook and Whittaker, 2012). However, Bennett (2012) asserts that this new system does not align with the money management patterns of many low-income households; threatening housing security for those that lack budgeting skills or prioritize other expenses over rent. The resulting rent arrears will also have an effect on the finances of housing associations and landlords, as well their willingness to let to claimants of UC (Homeless Link, 2018).

UC payments for couples are made as a joint payment into the nominated bank account of the "main claimant," which is often set as the man by default (Millar and Bennett, 2016). This approach disproportionately affects women by lessening their access to income and decreasing their economic autonomy, regardless of the stability of the family's finances (Millar, 2018). There is also potential for this system to foster financial abuse in unequal relationships, as abusive partners are enabled to control the couple's total income and limit the survivor's access to money (Fahmy and Williamson, 2018). However, requesting to split the payments on grounds of domestic abuse often puts women at greater risk, as the abuser will receive a notification informing them of this request (Howard, 2018). The result is a welfare regime that, in its attempts to lessen "welfare dependency," may be supporting "dangerous dependencies" in domestic violence and abuse (DVA) partnerships, a common and widely recognized cause of female homelessness (Fahmy and Williamson, 2018).
Meanings made by homeless support workers 
$\underset{4,4}{\text { JHASS }}$

280

\section{Third-sector pressures, universal credit and COVID-19}

Adverse emotional and financial effects have been reported by those who work in the third sector as well as by claimants. Geiger et al. (2018) suggests there has been an absence of partnership working in respect of developing collaborative support programs enabling individualized assistance and rehabilitation. This stems, in part, from a lack of provision within UC to allow implicit consent for the details of a case to be discussed with a support worker, who may be able to represent the client and interpret the information provided. Given that support workers have often been required to accompany "vulnerable" claimants to DWP meetings or submit a one-off entry in the client's online journal providing explicit consent, this is something that requires attention (Howarth et al., 2018).

Although this study was completed before the pandemic, it is recognized that financial and health-related challenges arising from COVID-19 have increased pressures on the third sector alongside the rising number of individuals requiring UC (Mackley and McInnes, 2021). Third-sector housing-support workers have seen an increasing demand since UC was implemented. This is likely to have increased because of the unprecedented circumstances of the COVID-19 crisis. Many housing insecure people have fallen through the cracks of a wide, yet unfair, net of support. Furloughed workers can be up to $£ 1,107$ per month better off on the more generous Job Retention Scheme and self-employed income support scheme than identical households who have been made redundant and in receipt of UC (Varney, 2020). Research from the National Housing Federation (National Housing Federation, 2020) highlights substantial staff shortages $(15 \%-25 \%)$ in some support services, owing to selfisolation and illness, making them financially unviable. Without adequate government funding, organizations will inevitably close seeing many vulnerable individuals who they support return to rough sleeping and increasing the costs in welfare, policing, housing, health and social care as a result.

Enhanced conditionality and sanctions, in UC, have weakened the housing safety net, particularly for claimants who struggle to navigate and, thereby, comply with the new regime. Yet, there is still a very limited body of research exploring these areas. This paper seeks to add a new dimension to the existing literature by exploring the views of third-sector housing support workers, as an important yet marginalized group, addressing the following question:

What are the experiences of homeless people, according to support workers, of the enhanced welfare conditionality and sanctions under Universal Credit?

\section{Methods}

This study developed an interpretative phenomenological analysis (IPA) with eight housing-support workers from five different support groups based in the South East and South West of England. IPA is a method that seeks to provide in-depth insight and unravel ambiguous, complex and emotionally laden phenomena (Eatough and Smith, 2017; Finlay, 2011). The fundamental aim behind IPA's idiographic approach is not to test a hypothesis or generate general conclusions, but to encourage researchers to examine the "part," the encounter with a participant, and the "whole," the researcher's drawing of experience and knowledge, to work their data in a non-linear, dynamic and iterative manner at various levels for a holistic analytical interpretation (Smith et al., 2009; Tuffour, 2017).

IPA was chosen over other qualitative research methods given its concern with interpreting and making sense of such experiences between the researcher(s) and participant(s) (Smith et al., 2009). We acknowledge that, what is captured of another's experience using IPA will always be provisional and indicative rather than definitive and 
absolute because of the researchers, and participant's (particularly given the latters' close relationships with homeless clients) inescapable contextual basis of their own experiences and interpretations. Consequently, a "perfect" understanding of the essence of the experience will always remain hidden (Larkin et al., 2006).

Through the use of semi-structured interviews, this study explored the "life worlds" of support workers for homeless people. This group, represented by paid and voluntary workers, is frequently ignored as they are not part of the official panoply of housing and social security workers. However, third-sector support workers offer face-to-face support and often have in-depth personal knowledge to help homeless people. They represent, for many, the first line of support. According to Dahlberg (2006), life worlds are structures of essential meanings that illuminate the central characteristics of a phenomenon; in this case, support-worker perceptions of homeless people's experiences of UC (Smith, 2004; Smith et al., 2009). The interviews covered such topics as the impact of sanctions and barriers that could prevent claimants from accessing their entitlements (Smith, 1996). By using a more conversational manner, it was envisaged that participants would shed light on the research question through the discussion of their client's experiences of the UC system (Denscombe, 2017). This included eight semi-structured interviews with individuals who work in the third sector supporting UC claimants who are homeless or at risk of homelessness.

The research was limited by the small sample size, the small number and geographical setting of locations and focus on third-sector workers. However, the rich qualitative data gathered of subjective experiences, from support workers with knowledge of working in the housing and welfare system, has provided a unique perspective on the UC debate concerning homelessness.

\section{Sampling}

IPA requires "selective" sampling to attain a homogeneous sample, allowing researchers, when examining individual experiences of an event, to identify and analyze the similarities and differences between each case and to uncover something within each individual experience, before attempting a comparative analysis of participant material (Finlay, 2011; Spinelli, 2005; Smith et al., 2009). A sample of eight participants was used for the study, applying the subsequent inclusion criteria: participants were required to work in the third sector with the homeless, or those at risk of homelessness, and to have knowledge of the effects (if any) UC was having on their clients' homelessness. Two participants worked in a voluntary capacity and six were employed. Participants were recruited from the first author's knowledge of the sector and by "snowballing," thereafter providing the foundations for forming a solid sample of participants, which may otherwise have proved difficult to access (Creswell, 2012). The limitations of this were recognized because people refer to those whom they know and given the similarity in the positions this sample occupy, there is an increased risk of sampling bias and margin error and results are likely to vary if a wider sample was used (Döringer, 2020). The sample reflects the participants' understandings at a given time and context and findings are not generalizable. Insights can also be eclipsed by the researcher's own interpretation (Döringer, 2020). However, precautionary steps were taken to consider and minimize potential issues throughout the data analysis, which used prior research, thus combining findings and analysis.

\section{Data analysis}

Interviews were audio recorded to facilitate transcription. Analyzing interview transcripts in IPA is iterative (Smith et al., 2009). This research followed Finlay (2011) in transcribing and examining interviews individually while building up a familiarity with the transcripts
Meanings made by homeless support workers

281 
JHASS 4,4 over multiple readings. Comments that were characteristic of the support workers' perceptions that were thought to be of interest and of significance were noted and emergent themes and topics developed from these (Smith et al., 2009). Themes that were present in at least half of the transcriptions were classified as recurrent, to allow for a wider interpretation of the phenomenon under investigation and offset the idiosyncratic qualities of IPA.

The themes and subthemes were compared and contrasted for interconnections. Generally, the analysis and presentation of the findings section of IPA research projects do not refer to literature, instead it presents a narrative account of the experiences as given by the participant. IPA is assumed to allow the experience to speak for itself, uninfluenced by the researcher's presumptions; the important elements that make this phenomenon distinctive and providing a greater insight into this limited and under-researched area (Finlay, 2011; Tuffour, 2017). However, we have deviated from this to set the experiences of support workers in this research context because this adds a richness to the data and adds to their policy and practice relevance. It allowed for an in-depth analysis of how support workers perceive that welfare recipients have experienced conditions and sanctions introduced under UC although recognizing that individuals are "self-interpreting beings," which involves active interpretation of the objects, people and events in their lives (Pietkiewicz and Smith, 2014, p. 8).

Ethical permission was gained in accordance with Bournemouth University's Research Ethics Code of Practice: Policy and Procedure (Checklist ID: 28258). To protect the anonymity of the participants and their organizations, names and places of work were kept confidential and anonymized in the findings.

\section{Findings and analysis}

The transcripts themes and sub-themes that reoccurred in at least half of the transcripts are presented here to summarize the impact of the enhanced conditionality and sanctions on the most vulnerable of claimants, homeless people (defined in broad ways and as understood by the support workers) and identified solutions to mitigate the impacts.

\section{Homelessness and barriers to conformity with conditionality}

Conditionality, and serious implications for non-compliance, has increased the pressures on claimants to secure employment (Dwyer and Wright, 2014; Taggart et al., 2020). There has been a significant impact on rough sleepers with learning difficulties, mental health and/or addiction problems:

Respondent one: Well, people who are rough sleeping have no awareness of day, date or time, so, especially if they have an addiction problem or mental health problem, they can't remember what they are doing from one day to the next. So, remembering to attend appointments is a big thing.

Respondents highlighted the struggles and barriers clients faced that hampered their ability to comply with UC conditions. Dwyer (2019) indicates that non-compliance, such as failure to attend an appointment, is often viewed as substantial grounds to impose sanctions regardless of the reasons for failure to comply or whether the DWP had been informed prior to the incident.

Despite formal attempts to support those facing homelessness and housing insecurity into paid employment, respondents agreed that there was a lack of awareness around the many barriers homeless people, however, defined, face in obtaining and maintaining paid work. These included poor physical or mental well-being; a lack of qualifications; ongoing 
drug or alcohol misuse; criminal records; and long periods of unemployment and economic inactivity.

Respondent four: You cannot make somebody change overnight, that takes a lot more counselling and a lot more work, not just a change in benefits I am afraid. So, then you really have to hold their hands and Universal Credit is not prepared to do that, we are here to do that.

This was often exacerbated by the online system (Cheetham et al., 2019). Many claimants have never used information technology (IT) or had no access to it, and there is little formal support for them, leaving third-sector staff responsible for helping clients navigate the digital system. Even with this help, clients were sometimes sanctioned owing to system errors through no fault of their own.

Respondent three: If you don't have access to a computer, you have to go to a public library to do it and that in itself is quite a humiliating process - having to go to a public library to manage and claim your benefits. If not then you would have to go and get help from the job centre, which is easier said than done [...] if you are a homeless person, that is a big worry it is another thing to add to that pile of insecurity.

Another respondent recounted the experience of a client who, because of their specific learning difficulties, could not understand the online system, leading to piling debt and threats of eviction:

Respondent seven: One of our clients, it was awful, he has got severe dyslexia doesn't read very well so that, for him, managing that (the online system) was really tough [...] he was getting himself into a lot of bother for not understanding what was needed and for not answering.

Respondents recognized the challenges of the online system for clients, supporting the claims that this disproportionately affects people who live chaotic lifestyles, lack the necessary IT skills, have poor literacy skills or struggle with mental health problems and/or additional needs (Reeve, 2017).

The "digital by default" system presents a "digital divide" for the most vulnerable claimants who face difficulties when trying to understand or abide by the conditions set out in their claimant commitment, which often results in unfair sanctioning (Reeve, 2017). Navigating a complex, degrading and frequently hostile system, prone to administrative errors, creates barriers for many claimants in accessing and claiming their full entitlement (Seddon and O'Donovan, 2013; Cheetham et al., 2019).

One respondent highlighted how the lack of understanding or support from the DWP and the job center has severe consequences on people's physical, mental and financial state:

Respondent eight: I think there is this myth out there that millions of people in England who are claiming benefits that shouldn't be and I can tell you that 99\% of clients are not capable of working [...] When that person is in an unwell state on top of that, they have to worry about Universal Credit and not being paid because they couldn't attend an appointment, it is ridiculous, but that is reality.

Taggart et al. (2020) states it is the most disadvantaged of claimants, those with low levels of education and/or work experience, learning difficulties and the homeless, who are likely to be adversely affected by the enhanced welfare conditionality and sanctioned as a result of non-compliance, exacerbating pre-existing inequalities and failing to account for mental health problems (Marks et al., 2017):

Respondent four: It is very patronising to have a decision maker who has been to school for 15 years, who doesn't know the person, who has been told that they must turn down $30 \%$ of claimants, for people who will never be able to work, who wouldn't even be able to attend an appointment or an
Meanings made by homeless support workers

283 


\section{JHASS 4,4}

interview because their anxiety level does not allow. They would not be able to hold down a job, they struggle to get out of bed in the morning, because of their mental health state.

\section{Financial and emotional impact of sanctions}

$\mathrm{UC}$ is characterized by a comprehensive system of tougher, stricter and more frequently issued sanctions than the legacy system, with some past claimants having faced up to three years of payment suspensions for failing to conform to welfare conditions, although sanctions are now more limited and COVID-19 has mitigated their use. Although tough, many have questioned the effectiveness of sanctions in reducing so-called "welfare dependency" (Dwyer and Wright, 2014; Cheetham et al., 2019. Sanctions are described as a deterrent rather than a punishment (Reeve, 2017), however, Dwyer (2019) describes the DWP's approach as adopting a "sanction first, investigate later" method. This is echoed by the following respondent:

Respondent six: I know people who have been sanctioned, for 30 days, 60 days, that is basically true punishment that those people are going without the means to live. They aren't going to be able to eat, struggle to survive and lose their homes.

When asked for examples, the respondent described how one of their homeless clients, who struggled with a drug addiction and mental health difficulties, found the formality of UC difficult and was repeatedly sanctioned for not meeting his claimant commitment conditions. As a result, he built up rent arrears and was eventually evicted. This supports evidence from Geiger $e t$ al. (2018) who highlights the lack of partnership working in regard to the utilization of associated support programs and the increased needs for individualized assistance and rehabilitation.

Respondent four explained that, because of the tougher sanction system and associated consequences: Now we see 60 to 80 people a day [. . .] all of those who have to be moved over to Universal Credit are in a worse condition, it has not been in their favour, every single one of them [...] the switch over is brutal [...] Unfortunately, we are dealing with the consequences, where the job centre doesn't seem to understand. They are not the ones who are going to bail them (the claimant) out.

Despite government reassurances that precautionary measures were used to protect vulnerable claimants, Patrick (2012) identified shortcomings in the implementation of these provisions. Respondents believed that UC did not "simplify the benefit system" or "incentivize paid employment" but negatively impacted recipients' finances, mental and physical well-being and social and family life. Managing the enhanced conditionality, paired with the threats of sanctions, worsened long-term health conditions and adversely affected claimant's mental health (Cheetham et al., 2019).

Respondent seven: I think it has just had a too big of an effect and I do believe that people have taken their lives because of it and I just thought nobody thought it through to be quite honest. They were like let's give them (the claimants) the responsibility, but actually they do not have the capability.

Cuts to social security are affecting physical and mental well-being through a combination of psychosocial and material pathways that involve greater financial hardship, debt, mental illness and self-harm (Dwyer, 2019). Consequently, all respondents reported an increase in their case numbers and the additional pressure associated with correcting the mistakes caused by the inconsistent and inaccurate advice provided by front-line and UC helpline staff was well captured by Respondent five, who said: 
This is the fourth year that the project has been running, year 1, we had 17 referrals into the project [...]. Year 2, we had 44 referrals into the project. Last year we had 53 and this year so far (as of March 2020), we have had 50 [...] There is only two members of staff [. . .] we can only take as many referrals as we can take and we do turn people down the increase has been high.

Sanctioning and higher rates of survival crime

According to Beatty et al. (2015), evidence has demonstrated that greater levels of crime were more prevalent in areas where higher rates of sanctions were imposed, with many homelessness organizations reporting that, as a result of sanctions, clients were resorting to survival theft or shoplifting. This was reported as a wider consequence of sanctions by respondents, who claimed their clients had to turn to survival crime to avoid serious hardship, housing insecurity and rising debt. This was captured by two respondents who expressed that:

Respondent seven: They are getting sanctioned for the most ridiculous things, they might have missed an appointment, or they have not read the blog properly or they have not updated their journal, and it can be for whatever reason and they're sanctioned and their money stopped [. . . ] you are pushing them into crime and all sorts of things[...] Ijust think sanctions aren't the way.

Respondent eight: I know people who shoplift on a regular basis, because they can't afford to live, because they have been sanctioned, or they have had their money cut, they have got dependents. It is ridiculous.

The DWP offer hardship payments of up to $60 \%$ of the claimant's original income to assist with rent, bills and other essential expenses during a period of sanctioning. Yet, the government's aggressive approach to debt collection "hurts more than it helps," as the high deductions from subsequent UC payments push claimants into spiraling debt, hardship and stress (HCWPC, 2018). This undermines the government's objective of making a fairer system that disincentivizes the "culture of worklessness"; instead, it creates barriers for claimants to find work and progress in employment (Keen, 2018). These concerns were echoed by respondents:

Respondent two: They say you can have some money, but you have to pay that back, so when you do get paid, what you get is a reduced rate and isn't always enough to get by, that can cause some problems.

Evidence in existing literature argues that debt also hampers the measures UC places to incentivize work and employment progression (Keen, 2018; HCWPC, 2018).

\section{Gendered perspectives: female homelessness, universal credit and domestic violence and abuse partnerships}

As Stephenson (2017) and Millar and Bennett (2016) note the nomination of a "main claimant," joint payments and earnings thresholds reinforce the regressive ideology of the male breadwinner model (Watson and Austerberry, 1986). This was evident in the interview with Respondent five, who stated:

I had a couple [...] the husband was too poorly to come out of the Hospital [...] So, the wife came over [...] we set up the account, said that she had a partner who also needed an account, then her account just went. You couldn't access her account without accessing his account [...] she couldn't carry on with her claim and it defaulted to him, the man, even though she was the first person, that to me is discriminatory [.. . I I am shocked that nobody has challenged that previously. 
JHASS 4,4

286

Following on from this, the respondent spoke about the potential implications of this design:

I had a couple, one of them with learning difficulties, he had complete control of all of the money, she was given a pittance. I mean she eventually left him, therefore, extricating herself from that joint Universal Credit account, it takes time, he has still got control of the money, she has got no financial freedom, because it is the joint account that it is being paid into [.. Jit is discrimination in my view.

This illustrates the concerns surrounding the impact of practices, such as the joint couple payments of the UC welfare reform on financial abuse in DVA partnerships, as abusive partners are afforded greater monetary control (Fahmy and Williamson, 2018). As Davidge et al. (2020) explain, this comes at a time where domestic abuse support services have been impacted by a lack of funding because of the government's punitive austerity measures.

According to Howard and Skipp (2015), this lack of economic support from the welfare state has made it increasingly challenging for survivors of domestic abuse to financially liberate themselves from their abusers, leading to an increased risk of poverty or homelessness post-separation.

\section{Conclusions}

UC may have been designed with good intentions; the removal of the 16-h work cap; simplification of the system; and assisting claimants back into employment. However, the DWP's lack of personalized understanding has perpetuated the idea that welfare dependency is a choice and that it is not the role of the state to help those in need but to sanction those not able to secure employment.

This research identified key recurring themes, including enhanced conditionality; the increased usage of unfair sanctioning; the "digital by default" system, which has generated a "digital divide" for claimants with no knowledge of or limited access to IT resources; the loss of financial control for women, particularly the joint couple payments in DVA partnerships; claimants resorting to survival crimes to avoid deprivation incurred by sanctions; and limited hardship payments, all of which have severe consequences on claimants' physical and mental well-being, as well as their financial and housing security.

To manage and mitigate the effects of $\mathrm{UC}$ would require a comprehensive review prior to its full rollout to claimants, preferably in the form of longitudinal research to understand the full extent of UC, conditionality and sanctions on claimants and the broader costs to public spending. To an extent, this is being addressed by Economic and Social Research Councilfunded research at the University of York (Welfare Conditionality Project, 2018) and the University of Bath (IPR, 2020), among others. However, it seems that there has been a significant impact on claimants with complex needs, often those at greater risk of homelessness, who are still subjected to the harsh conditions and sanctions.

Based on the findings, it is recommended that a full cost-benefit analysis of UC in partnership with third-sector workers is needed, with a specific focus in the following areas:

- Ensuring all frontline job center staff are fully trained and resourced to support vulnerable claimants before managed migration from the live service to the full service begins in remaining areas.

- Carry out a fully comprehensive review of UC and its effects on the mental health and financial security of vulnerable claimants, following data that emphasizes the impact of sanctioning and its link to the increase in survival crime.

- Trial and implement alternative options for claimants with lower digital literacy to submit a claim and manage their UC account. 
- Review the singular payment and conditionality threshold for couples, which give greater financial control to abusive partners in DVA relationships.

We also suggest there is a need for the recognition of the importance of support workers who assist claimants to make and manage their UC. Support workers (where permission is given by the claimant) should be granted access to their claimant's journal that would form a two-way information channel between the claimant and the DWP. This would be much more cost effective all round and reduce administrative costs and lessen the rates of Meanings made by homeless support workers sanctions for non-compliance.

More broadly, policy and practice could be improved through greater collaborative working between Job Centre Plus and Local Councils and the oversight of local partnerships to identify, engage and support claimants. Although almost all councils are now signed up to the new arrangements for UC, this partnership approach appears to have declined since the trials. We recommend greater collaborative planning, shares and agreed processes through local partnership boards. This could be achieved monitoring the impact of UC, targeted communications and recognizing those who are most at risk. Engaging with those most at risk using a targeted support approach to manage and mitigate the impacts of UC, and through building resilience through longterm response, such as housing and finance.

\section{References}

Alston, P. (2018), "Statement on visit to the United Kingdom, by professor Philip Alston, united nations special rapporteur on extreme poverty and human rights", London, Office of the United Nations High Commissioner for Human Rights, available at: www.ohchr.org/en/NewsEvents/Pages/ DisplayNews.aspx?NewsID=23881\&LangID=E (accessed 5 December 2018).

Anderson, P. (2014), Guidance on the Jobseekers Allowance (Homeless Claimants) Amendment Regulations 2014, Homeless Link, London.

Barker, N. (2018), "Figures suggest universal credit is driving homelessness and evictions", Inside Housing, available at: www.insidehousing.co.uk/news/news/figures-suggest-universal-credit-isdriving-homelessness-and-evictions-59468 (accessed 21 April 2020).

Beatty, C. and Fothergill, S. (2018), "Welfare reform in the UK 2010-2016: expectations, outcomes and local impacts", Social Policy and Administration, Vol. 52 No. 5, pp. 950-968.

Beatty, C., Foden, M., McCarthy, L. and Reeve, K. (2015), Benefit Sanctions and Homelessness: A Scoping Report, Crisis, London.

Bennett, F. (2012), "Universal credit: overview and gender implications”, in Kilkey, M., Ramia, G. and Farnsworth, K. (Eds), Social Policy Review 24: Analysis and Debate in Social Policy, Policy Press, Bristol, pp. 15-34.

Bramley, G. and Fitzpatrick, S. (2018), "Homelessness in the UK: who is most at risk?", Housing Studies, Vol. 33 No. 1, pp. 96-116.

Cheetham, M., Moffatt, S., Addison, M. and Wiseman, A. (2019), "Impact of universal credit in North East England: a qualitative study of claimants and support staff”, BMJ Open, Vol. 9 No. 7, pp. 1-9.

Creswell, J. (2012), Educational Research: Planning, Conducting and Evaluating Quantitative and Qualitative Research, 4th ed., Pearson Education, inc, Boston.

Crisis (2018), Everybody in: How to End Homelessness in Great Britain, Crisis, London.

Dahlberg, K. (2006), "The essence of essences - the search for meaning structures in phenomenological analysis of lifeworld phenomena", International Journal of Qualitative Studies on Health and Well-Being, Vol. 1 No. 1, pp. 11-19. 
$\underset{4,4}{\text { JHASS }}$

Davidge, S., Magnusson, L. and Samuel, M. (2020), The Domestic Abuse Report 2020: The Annual Audit, Women's Aid, London.

Dean, H. (2004), "Popular discourse and the ethical deficiency of 'third way' conceptions of citizenship", Citizenship Studies, Vol. 8 No. 1, pp. 65-82.

Dean, H. (2010), Understanding Human Need Social Issues, Policy and Practice, Policy Press, Bristol.

Denscombe, M. (2017), The Good Research Guide: For Small Scale Social Research Projects, 6th ed., Open University Press, London.

Department for Work and Pensions (2010a), "21st century welfare”, Department for Work and Pensions, London, available at: https://assets.publishing.service.gov.uk/government/uploads/ system/uploads/attachment_data/file/181144/21st-century-welfare-response.pdf (accessed 11 December 2019).

Department for Work and Pensions (2010b), "Universal credit: welfare that works", Department for Work and Pensions, London, available at: https://assets.publishing.service.gov.uk/government/ uploads/system/uploads/attachment_data/file/181145/universal-credit-full-document.pdf (accessed 11 December 2019).

Department for Work and Pensions (2012), Impact assessment about Universal Credit introduced under the Welfare Reform Act 2012, Department for Work and Pensions, London.

Department for Work and Pensions (2014), "Jobs and welfare reform: getting Britain working", available at: www.gov.uk/government/speeches/jobs-and-welfare-reform-getting-britain-working (accessed 1 May 2020).

Department for Work and Pensions (2017), "Universal credit: the six week wait", available at: https:// publications.parliament.uk/pa/cm201719/cmselect/cmworpen/336/33603.htm\#_idTextAnchor008 (accessed 10 November 2019).

Dobson, R. and McNeill, J. (2011), "Review article: homelessness and housing support services: rationales and policies under new labour", Social Policy and Society, Vol. 10 No. 4, pp. 581-589.

Döringer, S. (2020), “The problem-centred expert interview'. Combining qualitative interviewing approaches for investigating implicit expert knowledge", International Journal of Social Research Methodology, pp. 1-14, doi: 10.1080/13645579.2020.1766777.

Driver, S. (2009), "Work to be done? Welfare reform from Blair to Brown", Policy Studies, Vol. 30 No. 1, pp. 69-84.

Dwyer, P. (2004), "Creeping conditionality in the UK: from welfare rights to conditional entitlements", The Canadian Journal of Sociology, Vol. 29 No. 2, pp. 265-287.

Dwyer, P. (2016), "Citizenship, conduct and conditionality: sanctions and support in the 21st century welfare state", in Finger, M. Hudson, J. and Needham, C. (Eds), Social Policy Review 28 Analysis and Debate in Social Policy, Policy Press, Bristol, pp. 41-49.

Dwyer, P. (2019), Dealing with Welfare Conditionality: Implementation and Effects, Policy Press, Bristol.

Dwyer, P. and Wright, S. (2014), "Universal credit, ubiquitous conditionality and its implications for social citizenship", Journal of Poverty and Social Justice, Vol. 22 No. 1, pp. 27-35.

Eatough, V. and Smith, J. (2017), "Interpretative phenomenological analysis", in Willig, C. and StaintonRogers, W. (Eds), Handbook of Qualitative Psychology, 2nd ed., Sage, London, pp. 193-211.

Edmiston, D. (2017), "Welfare, austerity and social citizenship in the UK", Social Policy and Society, Vol. 16 No. 2, pp. 261-270.

Fahmy, E. and Williamson, E. (2018), "Poverty and domestic violence and abuse (DVA) in the UK", Journal of Gender-Based Violence, Vol. 2 No. 3, pp. 481-501.

Finlay, L. (2011), Phenomenology for Psychotherapists: Researching the Lived World, Wiley-Blackwell.

Fletcher, D., Batty, E., Flint, J. and McNeill, J. (2016), "Gamers or victims of the system? Welfare reform, cynical manipulation and vulnerability”, Journal of Poverty and Social Justice, Vol. 24 No. 2, pp. 171-185. 
Fletcher, D. and Wright, S. (2018), "A hand up or a slap down? Criminalising benefit claimants in Britain via strategies of surveillance, sanctions and deterrence”, Critical Social Policy, Vol. 38 No. 2, pp. 324-344.

Geiger, B., Garthwaite, K., Warren, J. and Bambra, C. (2018), "Assessing work disability for social security benefits: international models for the direct assessment of work capacity", Disability and Rehabilitation, Vol. 40 No. 24, pp. 2962-2970.

Gibson, H. (2015), "Between the state and the individual: 'big society' communitarianism and English conservative rhetoric", Citizenship, Social and Economic Education, Vol. 14 No. 1, pp. 40-55.

Meanings made by homeless support workers

289

Homeless Link (2018), Young and Homeless 2018, Homeless Link, London.

House of Commons Work and Pensions Committee (2018), Universal Support, The Department for Work and Pensions, London.

Howard, M. (2018), Universal Credit and Financial Abuse: Exploring the Links Summary and Recommendations, Women's Budgeting Group, London.

Howard, M. and Skipp, A. (2015), Unequal, Trapped and Controlled: Women's Experience of Financial Abuse and Potential Implications for Universal Credit, Women's Aid, London.

Howarth, P., Charlesworth, Z. and Ghelani, D. (2018), Universal Credit: making It Work for Supported Housing Residents, Policy in Practice, London.

IPR (2020), "Couples balancing work, money and care: exploring the shifting landscape under universal credit", available at: www.bath.ac.uk/projects/couples-balancing-work-money-and-careexploring-the-shifting-landscape-under-universal-credit/ (accessed 19 November 2020).

Jeffrey, R. (2018), "Making a universal credit claim”, London, Citizen's Advice, available at: www. citizensadvice.org.uk/Global/CitizensAdvice/welfare\%20publications/Making\%20a\%20Universal\% 20Credit\%20claim\%202018\%20-\%20final.pdf (accessed 2 March 2020).

Jones, K. (2019), "No strings attached? An exploration of employment support services offered by third sector support organisations", in Dwyer, P. (Ed.), Dealing with Welfare Conditionality: Implementation and Effects, Policy Press, Bristol, pp. 91-118.

Keen, R. (2018), Universal Credit: Why Are Sanction Rates Higher?, UK Parliament, London.

Kleynhans, S. and Weekes, S. (2019), From the Frontline Universal Credit and the Broken Housing Safety Net, Shelter, London.

Larkin, M., Watts, S. and Clifton, E. (2006), "Giving voice and making sense in interpretative phenomenological analysis", Qualitative Research in Psychology, Vol. 3 No. 2, pp. 102-120.

Lee, S. (2011), "We are all in this together': the coalition agenda for British modernisation”, in Lee, S. and Beech, M. (Eds), The Cameron-Clegg Government: Coalition Politics in an Age of Austerity, Palgrave Macmillan, Basingstoke, pp. 3-23.

Lister, R. and Bennett, F. (2010), "The new 'champion of progressive ideals'? Cameron's conservative party: poverty, family policy and welfare reform”, Renewal, Vol. 18 Nos 1/2, pp. 84-109.

Mackley, A. and McInnes, R. (2021), "Coronoavirus: universal credit during the crisis", available at: https://commonslibrary.parliament.uk/research-briefings/cbp-8999/ (accessed 18 January 2021).

Marks, A. Cowan, S. and McLean, G. (2017), "Mental health and unemployment in Scotland, Herriot Watt university and Napier University", available at: www.advocard.org.uk/wp-content/ uploads/2017/02/2017-02-Heriot-Watt-Mental-Health-Report-on-WCA.pdf (accessed 12 March 2020).

Millar, J. (2018), "Self-responsibility and activation for lone mothers in the United Kingdom”, American Behavioral Scientist, Vol. 63 No. 1, pp. 85-99.

Millar, J. and Bennett, F. (2016), "Universal credit: assumptions, contradictions and virtual reality", Social Policy and Society, Vol. 16 No. 2, pp. 169-182.

National Housing Federation (2020), The Impact of COVID-19 on Homelessness, Rough Sleeping, and the Private Rented Sector, National Housing Federation, London. 


\section{JHASS 4,4}

O'Hara, M. (2020), The Shame Game: Overturning the Toxic Poverty Narrative, Policy Press, Bristol.

Office for Budget Responsibility (2019), "Welfare spending: universal credit", available at: https:/obr. uk/forecasts-in-depth/tax-by-tax-spend-by-spend/welfare-spending-universal-credit/ (accessed 23 November 2019).

Olsen, G.M. and Benjaminsen, L. (2019), "Homelessness and social policy", in Greve, B. (Ed.), Routledge Handbook of the Welfare State, 2nd ed., Routledge, Abingdon, pp. 393-406.

Patrick, R. (2012), "All in it together? Disabled people, the coalition and welfare to work", Journal of Poverty and Social Justice, Vol. 20 No. 3, pp. 307-322.

Pennycook, M. and Whittaker, M. (2012), Conditions Uncertain. Assessing the Implications of Universal Credit in-Work Conditionality, The Resolution Centre, London.

Pietkiewicz, I. and Smith, J. (2014), "Practical guide to using interpretative phenomenological analysis in qualitative research psychology", Psychological Journal, Vol. 20 No. 1, pp. 7-14.

Reeve, K. (2017), "Welfare conditionality, benefit sanctions and homelessness in the UK: ending the 'something for nothing culture' or punishing the poor?", Journal of Poverty and Social Justice, Vol. 25 No. 1, pp. 65-78.

Seddon, J. and O'Donovan, B. (2013), "The Achilles' heel of scale service design in social security administration: the case of the United Kingdom's universal credit", International Social Security Review, Vol. 66 No. 1, pp. 1-24.

Smith, J. (1996), "Beyond the divide between cognition and discourse: using interpretative phenomenological analysis in health psychology", Psychology and Health, Vol. 11 No. 2, pp. 261-271.

Smith, J. (2004), "Reflecting on the development of interpretative phenomenological analysis and its contribution to qualitative research in psychology", Qualitative Research in Psychology, Vol. 1 No. 1, pp. 39-54.

Smith, J., Flowers, P. and Larkin, M. (2009), Interpretative Phenomenological Analysis: Theory, Method and Research, Sage, London.

Spinelli, E. (2005), The Interpreted World: An Introduction to Phenomenological Psychology, 2nd ed., Sage, Thousand Oaks, CA.

Standing, G. (2016), The Precariat: The New Dangerous Class, Bloomsbury, London.

Stephenson, M. (2017), Universal Credit: A Briefing from the UK Women's Budget Group, Women's Budget Group, London.

Taggart, D., Mehta, J., Clifford, E. and Speed, E. (2020), “They say jump, we say how high?’ Conditionality, sanctioning and incentivising disabled people into the UK labour market", Disability and Society, pp. 1-21, available at: http://doi.org/10.1080/09687599.2020.1766422

Tuffour, I. (2017), "A critical overview of interpretative phenomenological analysis: a contemporary qualitative research approach", Journal of Health Care Communications, Vol. 2 No. 4, pp. 1-5.

Varney, C. (2020), "The future of the welfare state after Coronavirus", available at: https://policyinpractice. co.uk/the-future-of-the-welfare-state-after-coronavirus/ (accessed 22 November 2020).

Watson, S. and Austerberry, H. (1986), Housing and Homelessness: A Feminist Perspective, Routledge and Kegan Paul, London.

Watts, B., Fitzpatrick, S., Bramley, G. and Watkins, D. (2014), Welfare Sanctions and Conditionality in the UK, Joseph Rowntree Foundation, York.

Webster, D. (2019), Briefing Benefit Sanctions Statistics May 2019, Child Poverty Action Group. London.

Welfare Conditionality Project (2018), "Final findings report welfare conditionality project 2013-2018", available at: www.welfareconditionality.ac.uk/wp-content/uploads/2018/06/40475_WelfareConditionality_Report_complete-v3.pdf (accessed 19 November 2020).

Wright, S. (2012), "Welfare-to-work, agency and personal responsibility", Journal of Social Policy, Vol. 41 No. 2, pp. $309-328$. 
Wright, S., Dwyer, P., McNeill, J. and Stewart, A. (2016), First Wave Universal Credit Findings, The Economic and Research Council, Swindon.

\section{Further reading}

Blackmore, K. and Warwick-Booth, L. (2013), Social Policy: An Introduction, 4th ed., Open University Press, Berkshire.

Field, F. and Forsey, A. (2016), Fixing Broken Britain? An Audit of Working-Age Welfare Reform since 2010, Civitas, London.

Marshall, T. (1950), Citizen and Social Class, and Other Essays, Cambridge University Press, Cambridge.

Oakley, M. (2014), Independent Review of the Operation of Jobseeker's Allowance Sanctions Validated by the Jobseekers Act 2013, The Department for Work and Pensions, London.

Pautz, H. (2017), "Think tanks, tories and the austerity discourse coalition”, Policy and Society, Vol. 37 No. 2, pp. 155-169.

Royston, S. (2012), "Understanding universal credit”, Journal of Poverty and Social Justice, Vol. 20 No. 1, pp. 69-86.

Smith, J. (2007), "Hermeneutics, human sciences and health: linking theory and practice", International Journal of Qualitative Studies on Health and Well-Being, Vol. 2 No. 1, pp. 3-11.

Stewart, A. and Wright, S. (2014), "Universal credit, ubiquitous conditionality and its implications for social citizenship", Journal of Poverty and Social Justice, Vol. 22 No. 1, pp. 27-35.

Titmuss, R. (1958), Essays on 'the Welfare State', George Allen and Unwin, London.

Yuval-Davis, N. (2015), "Situated intersectionality and social inequality", Raisons Politiques, Vol. 58 No. 2, pp. 91-100.

\section{Corresponding author}

Jonathan Parker can be contacted at: parkerj@bournemouth.ac.uk
Meanings made by homeless support workers 